\title{
Investor Awareness and Investment on Equity in Nepalese Capital Market
}

\author{
Sudarshan Kadariya \\ Institute of Banking \& Management Studies, Kathmandu \\ Email: su.kadariya@gmail.com \\ Phul Prasad Subedi \\ Janamaitri Multiple Campus, Kathmandu \\ Bharati Joshi \\ Reader, Siddhanath Multiple Campus, Kanchanpur \\ Ram Prasad Nyaupane \\ HOD, Accounting \& Finance, Janamaitri Multiple Campus, Kathmandu
}

\begin{abstract}
Nepalese financial sector has been growing rapidly so does the growth of capital market, which is dominated by the Financial Sector. The rapid growth of capital markets has raised the question of sustainable development of this sector. For the long term growth, it has some preconditions: the stakeholders' literacy and awareness level, the access to information, and ability to analyze them for the financial decision making. The sample size is determined as 100 stock investors in the secondary market and the response rate is 73 percent. The study find that the equity investors are aware and their level of awareness is high compare to needed level, aware equity investors have more chances of holding high volume of equity investment and there is problem on access to information for equity investors in secondary market.
\end{abstract}

Key words: Access, Awareness, Information, Investment, Stock Market

\section{BACKGROUND}

The inception of the capital market has been provided investment opportunities for individual and institutional investors in Nepal. The investment being the current sacrifice of spending for the future benefits and the capital formation is an essential macroeconomic parameter that enlarges the economic activities in the economy. The capital market acts as a mechanism that creates investment alternatives for the saving groups and long-term fund for individuals, institutions, and for the government. The history of the capital market was began in early seventeen century, the Amsterdam Stock Exchange is considered as the oldest stock exchange in the world which was started in 1602 followed by Paris Bourse in 1724 in Paris, France. The Bombay Stock Exchange which was established in 1875 is a pioneer stock exchange in South Asia. The practice of stock exchange in Nepal is of recent phenomenon which was started after issuance of common stock by Biratnagar Jute Mills Limited in 1937 (A.D.) whereas the oldest existing stock certificate was issued in 1606 for a Dutch company (Vereinigte Oostindische Compaignie). The history of securities exchange in Nepal shows that the first amendment in Securities Exchange 
Act, 1983 in 1993 paved the way for the restructuring of stock market in Nepal, which led to establish Securities Board of Nepal (SEBON) in 1993 with a mandate to regulate and develop the stock market. The Act also led to convert the then Securities Exchange Centre (SEC) into Nepal Stock Exchange (NEPSE), a fullfledged open-out-cry trading system with the induction of stock brokers in January 13,1994 . With the existence of stock exchange, numbers of financial institutions, investment groups and independent investors have been engaging in financial sector in term of their association in banking and finance, insurance, manufacturing and service industries and hydropower sectors. As a result, the practitioners and beneficiaries or the investment communities have grown tremendously in the short period. Such speedy growth also raised the issue of the quality of growth.

Capital market have significant stake on gross domestic product (GDP) of the national economy which creates the employment opportunities through capital formation and growth for the economy as a whole. But, only the existence of the capital market does not guarantee the significance contribution for the GDP and economic growth. The mechanism created the micro-level saving mobilization, an opportunity and challenges, too. The financial literacy and awareness level might be the crucial elements for the healthy growth of the market. The term investor awareness has been used in investor communities frequently. It describes the investor literacy or knowledge about the investment environment or about the market. The level of awareness usually measures the investors' exposure and knowledge or information about the industry as a whole. It is significant since investors are expected to make their investment decisions based on these information and knowledge.

Investor awareness is the knowledge of investment and about the important updates of the market. To expand and to achieve the sustainable growth of economy, investor awareness and their commitment for the long-term investment play the vital role. Thus, it is expected that the awareness and the commitment move in the same direction, and their association contributes a lot to the economic development. Capital market which is classified into primary market - raise the seed capital through initial public offering and the secondary market - the only platform which retains the long-term investment through exchange of the securities. More specifically, secondary market provides liquidity to the economy through the role of financial intermediaries and those intermediaries have directly connected with the individual investors. Thus, they might be sufficient room at the end of brokerage firms and the financial intermediaries to play vital role for creating investor awareness in Nepalese financial market.

\section{Statement of the problem}

Investors in the capital market have been fuelling for the economy and the stock exchange has been contributing like as lubricants. In this process, it is essential that all the information have to be identified and circulated to the buying and selling segments so that the efficient market mechanism will be created. The efficiency of the market indicates the replication of the information into stock price, as assuming that no information is costless. Every information whether issued by the institutions or leak as the private information carry certain cost or benefits so that it should be 
reflected within a security's price sooner or later. The investor can use such information to make the perfection of their investment decisions and to be awareness about the facts which contributes for efficient market operation.

It has been experiencing that SEBON, the apex regulator has been limited awareness programs - workshops and seminars, training programs, street campaigning, etc. The listed companies and the brokerage firms are yet to be perceived that the importance of similar programs. Most of the stock investors have been lacking the timely and reliable information which help to shape the rational investment decision. It is the fact that the development of capital market can be accelerated by only by educating the investment communities or the stakeholders in terms of their risk and return on investment, investment objectives, alternatives, investment decision making processes, etc. SEBON, Nepal Stock Exchange (NEPSE), Ministry of Finance (MoF), Nepal Rastra Bank (NRB), brokerage firms, and other private institutions have been spending their scare resources for investors' education and awareness from different perspectives. But, the market instability or the frequent ups and downs from the inception of the exchange practices raised the question of their effectiveness.

The prominent issues in the stock market might be the fluctuating stock market indices, the Capital centric trading system, limited numbers of dominant investors, and their influences in stock market. Kafle (2007) stated that the stock market is bullish and getting to new peaks, there are numbers of contributing factors out of them investors' awareness on the risk return and investment profile is the one. The major task of the securities regulating authorities is to protect investors' right and to provide the congenial trading environment with confidence and commitment. The development and expansion of the current infrastructure and the facilities is the another aspect. There is no the practice that regulators provides the specific investment advice, regulators should not recommend the purchase or sale of particular stocks. Similarly, they should not provide particular strategies to guide investors' investment decisions. But, the authority can do well and compel to do others is to disseminate the timely and reliable information that can enhance the awareness level of the investment communities.

Investor awareness is interchangeably used for terms like investor literacy, investor education, investor knowledge, etc because all of them help to create attentive investors. The potential benefits of investor awareness in third world economies are considerable. Thus, the justifications of the study are presented in light of the following points as below:

1. Aware investors play important watchdog roles which increase the likelihood that the regulating bodies can identify the potential market anomalies prior to its occurrence.

2. Aware investors can also better choose investment alternatives that are most appropriate for them in light of their individual circumstances such as age, wealth, income, debt, and years to retirement etc.

3. Investor awareness has become more important with the rise in popularity of the internet which may bring tools for initial investors into the security markets. On the other hand, awareness helps to make them up-to-date with the 
investment environment and provides tools to assess the risks associated with their portfolios.

4. Investor awareness also helps to develop the skill of investors to protect themselves against fraud and other malpractices.

5. Investor awareness helps to maximize the impact on use of limited resources of government agencies.

Thus, the study tries to help to create the importance of awareness and stock investment in financial market. The aware investor and stakeholders with efficient market exposure can perceive and get the required information to achieve their investment goals. The sources of the information might be different and the acquisition of the required information might be the other issue for stock investors. The rapid growth of the information technology (IT) sector has provided the one stop information accessibility. The internet provides cost-effective information to a large number of investors, as well as to the media people and others who directly or indirectly engage in investor awareness efforts.

With these brief statements, the study focuses on the following issues:

a) What is the extent of awareness of common stock investors?

b) What are the reasons investors do not want to hold their investment for long term?

c) Do the investors have optimum level of market access and awareness? What they need to be?

d) Do the information dissemination and role of concern authorities are sufficient to create awareness?

e) What is the perception of equity investors' toward advertisement to create awareness?

f) Do the investors feel that existing brokerage firms are sufficient to provide the services?

g) Is there necessity of new stock exchange to expand stock investors' awareness?

h) Why the media and the news coverage influence the stock prices?

i) How for the stock investors rely on their own expertise and awareness in decision making?

j) How could the awareness level determine the investment level?

The major objective of the study is to find the level of awareness among the stock investors and to find the extent of relationship between investor awareness and volume of equity investment in secondary market. Further the aims to identify the level of equity investors' access to market information.

The study formulates the following testable statement that can be tested in the following sections. The null hypothesis has been presented as follows:

$\mathrm{H}_{0}$ : There is no significant difference in frequency distribution between less aware and aware equity investors.

$\mathrm{H}_{0}$ : There is no significant relationship between investor awareness and investment on equity.

$\mathrm{H}_{0}$ : There is no problem on access to market information for equity investors. 


\section{REVIEW OF LITERATURE}

This section presents the review of some of the major previous studies in prevailing literature that provides some useful insight for the study.

\section{Table 1: Analysis of some of the major previous studies}

\begin{tabular}{|c|c|}
\hline Author (Year) & Major Findings \\
\hline Fodor (2008) & $\begin{array}{l}\text { Lack of investor awareness campaigns lead to the financial crime in the capital } \\
\text { market. Like the increase in security enforcement increases the number of } \\
\text { arrests. Adversely, increases in investor awareness campaigns leads to decrease } \\
\text { in financial crime. }\end{array}$ \\
\hline $\begin{array}{l}\text { Al-Tamimi and } \\
\text { Kali (2009) }\end{array}$ & $\begin{array}{l}\text { There is a significant relationship between financial literacy and investment } \\
\text { decisions. }\end{array}$ \\
\hline Al-Tamimi (2006) & $\begin{array}{l}\text { The most influencing factors for financial decisions are, in order of importance - } \\
\text { corporate earnings, get rich quickly and stock marketability, past performance of } \\
\text { firm's stock, government holdings and creation of organized financial markets. In } \\
\text { addition, religious reasons and family member opinions have least influence. }\end{array}$ \\
\hline Baidhya and & Awareness increase amongst the general public about the capital market, \\
\hline Parajuli (2004) & $\begin{array}{l}\text { regarding nature of risk and return, through promotional campaigns, seminars, } \\
\text { publications, and programs in FM/TV etc. }\end{array}$ \\
\hline Kafle (2007) & $\begin{array}{l}\text { The stock market is bullish and getting to new peaks, there are numbers of } \\
\text { contributing factors out of them investors' awareness on the risk return and } \\
\text { investment profile is the one. }\end{array}$ \\
\hline Paudyal (2010) & $\begin{array}{l}\text { Nepal particularly can learn from Indian market in the areas of the functioning of } \\
\text { stock exchange, mutual funds, central depository system of securities, } \\
\text { instruments diversification, investors' education and awareness building, adoption } \\
\text { of information technology and opening the secondary market for NRN and foreign } \\
\text { institutional investors (FIIs). Regarding investors' education and awareness, India } \\
\text { has created National Institute of Securities Market (NISM) with huge physical } \\
\text { infrastructure with the collaboration of industrial houses and different universities. }\end{array}$ \\
\hline Policy Research & Obviously, the financial crisis of 2008 has heightened institutional as well as \\
\hline Inst & individual investors' awareness of risks. \\
\hline $\begin{array}{l}\text { Christelis et al. } \\
\text { (2007) }\end{array}$ & $\begin{array}{l}\text { Policy intervention to improve the quality of financial information and investors' } \\
\text { awareness depend crucially on the extent to which cognitive abilities affect } \\
\text { financial decisions. }\end{array}$ \\
\hline $\begin{array}{l}\text { Ame } \\
\text { Zelde }\end{array}$ & $\begin{array}{l}\text { Within and across countries there is wide heterogeneity in stockholding, in } \\
\text { particular with respect to investors' wealth, education and horizon. }\end{array}$ \\
\hline (2006) & There is an association between stockholding and computer and Internet use. \\
\hline $\begin{array}{l}\text { Van Rooij et al. } \\
\text { (2007) }\end{array}$ & There is an association between stockholding and financial literacy. \\
\hline $\begin{array}{l}\text { Lusardi and } \\
\text { Mitchell (2006) }\end{array}$ & Negative association between planning for retirement and financial education. \\
\hline $\begin{array}{l}\text { Policy Research } \\
\text { Institute (2008) }\end{array}$ & $\begin{array}{l}\text { Obviously, the financial crisis of } 2008 \text { has heightened institutional as well as } \\
\text { individual investors' awareness of risks. }\end{array}$ \\
\hline $\begin{array}{l}\text { Graham et al. } \\
(2005)\end{array}$ & $\begin{array}{l}\text { Investors who claim to understand investment products hold more efficient } \\
\text { portfolios. }\end{array}$ \\
\hline $\begin{array}{l}\text { Bernheim and } \\
\text { Garrett (2003) }\end{array}$ & $\begin{array}{l}\text { Workers' saving choices are indeed affected by the employer-based programs of } \\
\text { financial education. }\end{array}$ \\
\hline t al. (2007) & Investors with low financial literacy are also less likely to invest in stocks. \\
\hline $\begin{array}{l}\text { Volpe et al. } \\
(2002)\end{array}$ & $\begin{array}{l}\text { The online investors should have more knowledge than normal investors to } \\
\text { succeed in the securities market because they are more likely to be sounded by } \\
\text { financial misinformation and manipulation. Investors' knowledge varied with } \\
\text { people's education, experience, age, income and gender. }\end{array}$ \\
\hline $\begin{array}{l}\text { Mirshekary and } \\
\text { Saudagaran } \\
\text { (2005) }\end{array}$ & $\begin{array}{l}\text { Investors make the financial decisions based on the information acquired from } \\
\text { annual report, oral information and published daily share price as the major } \\
\text { sources. On the other hand, the least influencing factors are; advice of friends } \\
\text { and acquaintances, tips and rumors, and stockbrokers' advice. }\end{array}$ \\
\hline
\end{tabular}


Based on the review of some of the major earlier studies, it is realized that there is a specific research gap in area of investor awareness in Nepalese context. Similarly, investors are keen to get the information but what is their status of access to market information is the another area of the study. Thus, this study tries to blend both scopes in an effort.

\section{METHODOLOGY}

The research design employed for the study are descriptive and correlation research design with due consideration of the research objectives of the study. The descriptive research design is a fact-finding operation searching for adequate information. It is undertaken in order to ascertain and be able to describe the characteristics of the variables of interest. The descriptive design generally employed to assess the opinions, behaviors, or the characteristics of a given population. The descriptive research design is selected for the study to learn the profile of the respondents, presentation and description of the data collection, and to describe the characteristics of the investors in the Nepalese stock market. The correlational research design on the other hand is used to obtain the description of the phenomena and to ascertain the extent of relationship of two variables. In general, the magnitude of a correlation depends upon the extent to which an increase in one variable is accompanied by an increase in the other. When the change in one variable leads to specific changes in another, the two variables are said to be covary or in other words, the relationship between them exist. In the correlational relationship, changes in one variable accompany changes in another and the magnitude of the changes range between perfect positive correlation $(+1)$ to perfect negative correlation $(-1)$ and no correlation when the coefficient is 0 . A positive correlation indicates that the scores move together, both increasing or both decreasing. A negative correlation indicates that as scores on one variable rise, scores on the other decreases. The correlational research design is employed for the study to identify how strongly the selected variables are related or delineating the association of the variables.

Equity investors in the secondary market are considered as the population of the study. Nepalese capital market is characterized with semi-automated trading system, central database/depository system is going to be installed. At present there is no formal source to state the number of investors. Thus, this study is based on the infinite population of common stock investors in the secondary market.

The study is based on the collection of primary data. Questionnaire method is adopted to explore awareness and to know the access in market information. Investors were requested to respond to a total of 37 statements comprises 21 yes/no questions designed to know the extent of awareness, 5 likert items with 1 to 4 scale developed to identify the investors access to information, 4 statements of yes/no questions and 1 open question were formulated in suggestions section, and 6 personal questions were asked to know the demographic characters of the respondent. The content of variables in stated questionnaires were identified through review of literatures and consultation with academician and experts. Valid questionnaires were developed keeping in mind that the objectives of the study. Since, the objective of the study is to construct the relationship between awareness 
level and volume of investment; personal questionnaire were developed in a manner to identify the level of investment of each respondent.

Systematic calculation for determination of sample size in infinite population for this research has not been used. 100 questionnaires, 50 in Nepali text and 50 in English language were produced and most of them were distributed in three trading observation floor at the brokerage firms and few were distributed within family and friends circle. Clear description about the purpose of the research and objectives of the work is stated at the beginning of the questionnaire. In case of oral enquiry, available members of the research team were employed to justify and describe the issues. Out of distributed questionnaire, 73 were collected and 65 were qualified for the research purpose. The remaining 8 responses were excluded because of incomplete data. Thus, the response rate of this study is 73 percent and valid response rate is 65 percent. For the matter of incorporating diversified respondents, responses were collected from the banking, academic, government, and business sectors.

There is inverse relationship between level of significance and the sample size. The sample size of this research was determined as 100 . Generally, sample size which is more than 50 is considered as the statistically accepted sample size but for the scope of this study remains on all the equity investors in Nepalese capital market. Thus, the level of significance for the study is determined as $5 \%$ and it is not determined as $1 \%$ considering the large sample size.

Since the priori of the study is not the directional or the objectives of the study are not concentrated on certain dimensions, thus, two tailed test is applied for hypothesis testing. For the data analysis, selection of the statistical tools is based on the normality test. For mean test to support the objective 2, One-Sample t-test (parametric) is selected but the contradiction is; in case of the sample size is greater than 30, z-test is the appropriate. Moreover, the statistical software like Statistical Package for Social Science (SPSS) has the facility of One-Sample t-test which follows the normal distribution and also applicable for large sample mean test. Thus, One-Sample t-test is applied. On-probability sampling design was used due to infinite population and convenience sampling technique was adopted to draw the sample.

Since, the exam type yes/no questions were asked to the respondents to explore their level of awareness thus, for data analysis concerning the first objective, theoretical framework was designed accordingly. On the other hand, reliability test is conducted for scale evaluation. The calculated Cronbach's Alpha is 0.751 with four statements for the second objective. As a general rule, a coefficient greater than or equal to 0.70 is considered acceptable and a good indication of construct reliability (Nunnally, 1978). To get the accepted level of Cronbach's Alfa, statement 2.1 is removed. The corresponding values of Cronbach's Alfa if item deleted of those retained statements are presented in Table 2. 
Table 2: Cronbach's Alpha Test (for objective 2) Statements

2.3 Brokerage firms have been providing sufficient trading information

2.4 Listed companies have been disclosing require information on time.

2.2 NEPSE has been providing sufficient market information.

2.5 Newspapers \& magazines have allotted sufficient space for economic issues and for market information

The benchmarks of categorization for each statements and variables (investor awareness and access to information) are presented in Table 3.

Table 3: Benchmark for classification of variables

\begin{tabular}{lrr}
\hline Description (Objective 1) & Description (Objective 2) & Benchmark \\
\hline Less Aware & Low Access & $50 \%$ \& Below \\
Aware & Satisfactory Access & $50-70 \%$ \\
Fairly Aware & Fairly Access & $70-85 \%$ \\
Highly Aware & Highly Access & $85 \%$ \& Above \\
\hline
\end{tabular}

For the selection of appropriate statistical tools, normality test; one-sample Kolmogorov-Smirnov was conducted. The asymptotical significance value of investor awareness is 0.114 . Thus, the distribution is normal and the parametric test - Pearson Correlation is selected to determine the first objective. Similarly, for the second objective, asymptotical significance value is 0.706 which is greater than 0.05 . Thus, the population is normal and parametric test - One Sample t-test is conducted to test the hypothesis that there is problem on access in market information for equity investors. For t-test, 0.50 is assumed as population mean or test value.

The collected responses were entered into SPSS and analyzed through appropriate statistical tools and techniques, which were relevant to draw the information required to meet objectives of the study.

\section{Theoretical framework}

Investor awareness is the outcome of multiple interacting efforts made by the investor own-self, listed companies, stock exchange, government, financial intermediaries, media, and so on which play the role in investment environment. Basically, investors get aware through their exposure on investment community, economic issue analysis, number of participation in investment training, workshops, formal education, learning expectation, amount of media coverage, number of awareness campaign, etc. The researchers are confined these variables into 21 yes/no questionnaires and the cut-off point is $50 \%$. For instance, if a respondent 
have $50 \%$ and less "yes" responses/agreement is considered as less aware/low access.

The framework to convert categorical responses into numeric value corresponding to investor awareness (for objective 1 ) is calculated as:

IA $=\quad$ (Sum of 'Yes' response of ET, AI, US and LE)

Where,

ET = Formal education and training

US $=$ Understanding of subjects

$\mathrm{AI}=$ Access to information

$\mathrm{LE}=$ Learning expectation

$\mathrm{N}=$ Total number of questions

Similarly, equity investors' access to market information (for objective 2) numeric responses can be determined as:

AI $=$ (Summated scale responses on Likert items)

$$
\mathrm{N}
$$

Where,

$\mathrm{N}=$ Total Likert items $\mathbf{x}$ Scale

Since, the measurement of the variables IA and AI are in percentile form. Thus the values of these variables are restricted between 0 and 1 .

\section{RESULTS AND DISCUSSIONS}

The analysis was based on the revised list of variables after considering Cronebach's Alpha at satisfactory level. The retained 10 variables are the base to determine the investor awareness. Demographic characters with level of investor awareness and access to market information is presented in Table 4 and the descriptive statistics is presented in Table 5 as follow. The questionnaire asked each respondent to provide demographic data that included age, sex, sector of employment, academic background, and level of equity investment.

The characteristics of respondents showed about $42 \%$ of the respondents lie in age group 35 to 45 years, with respect to gender $83 \%$ are male and remaining female investors, about $31 \%$ of respondent are individual investor, similarly around $51 \%$ characterize the academic background of masters and above and about $43 \%$ respondents are from the investment level 5 to 25 lakhs. 
Table 4: Respondent's Characteristics

\begin{tabular}{llrr}
\hline Characteristics & Category & Frequency & Percentage \\
\hline Age & $25-35$ & 24 & 36.92 \\
& $35-45$ & 27 & 41.54 \\
Sex & $45-55$ & 12 & 18.46 \\
Sector of employment & Above 55 & 2 & 3.08 \\
& Male & 54 & 83.08 \\
& Female & 11 & 16.92 \\
& College/campus & 11 & 16.92 \\
& Bank/finance & 7 & 10.77 \\
& Government office & 8 & 12.31 \\
& Private business & 19 & 29.23 \\
Academic background & Others (individual & 20 & 30.77 \\
& investor) & & \\
& SLC & 2 & 3.08 \\
& Intermediate & 3 & 4.62 \\
& Bachelor & 27 & 41.54 \\
Level of investment & Masters and above & 33 & 50.77 \\
& Below 5 lakh & 23 & 35.38 \\
& 5 to 25 lakh & 28 & 43.08 \\
Investor Awareness & 25 \& above & 14 & 21.54 \\
& Less Aware & 3 & 4.62 \\
& Aware & 9 & 13.85 \\
& Fairly Aware & 27 & 41.54 \\
& Highly Aware & 26 & 40.00 \\
& Low Access & 18 & 27.69 \\
& Satisfactory Access & 32 & 49.23 \\
& Fairly Access & 12 & 18.46 \\
& Highly Access & 3 & 4.62 \\
\hline
\end{tabular}

This study result show that about $42 \%$ of total investors are fairly aware and around $49 \%$ of respondents lie corresponding to satisfactory access. In totality, more than $50 \%$ investors lie in awareness and access categories. 
Table 5: Descriptive statistics of investor awareness and access to information

\begin{tabular}{lrrr}
\hline Statistics & $\mathbf{N}$ & Investor Awareness & Access to information \\
\hline Mean & 65 & 0.785 & 0.613 \\
Median & 65 & 0.810 & 0.625 \\
Mode & 65 & 0.810 & 0.625 \\
Std. Deviation & 65 & 0.125 & 0.163 \\
Minimum & 65 & 0.476 & 0.313 \\
Maximum & 65 & 0.952 & 1.000 \\
\hline
\end{tabular}

From the Table 5, the statistics shows that mean response of investors' awareness is 0.785 which is greater than the cutoff point 0.50 thus the result of this study shows the equity investors in secondary market are aware, more specifically, investors are fairly aware. On the other dimension, mean response of equity investors in terms of access to market information is measured as 0.613 which is also greater than benchmark 0.50 thus, the another result of this study is that equity investors have access to information, more specifically, investors have satisfactory access to market information.

Correlation analysis between investor awareness and level of investment The parametric test, Pearson Correlation provides the degree of association between two variables; investor awareness and level of investment is presented in the Table 6. The result shows that there is positive relationship between two variables and it is significant at the 0.05 level of significance. Thus, the alternative hypothesis i.e. there is significant relationship between investor awareness and investment on equity is accepted.

Table 6: Pearson Correlation (Parametric) Description Level of investment

Investor Awareness $0.290 *$

Sig. (2-tailed)

$\mathrm{N}$

${ }^{*}$ Correlation is significant at the 0.05 level (2-tailed).

\section{Contingency table of investor awareness and level of investment}

The Table 7 shows the frequencies corresponding to different classes of investor awareness with classes of investment. The frequencies with indication of percentage based on total responses are presented in each category. Investor awareness is equally important in each level of investment thus the frequency distribution corresponding to investment is high. The extreme frequencies in cross tabulation shows that $0 \%$ less aware investor invests in 25 lakh \& above and $32.31 \%$ highly aware investors have 5 to 25 lakh equity investment in secondary market. 
Table 7: Cross tabulation of investor awareness and investment level

\begin{tabular}{lrrrrrrrr}
\hline $\begin{array}{l}\text { Investor } \\
\text { Awareness } \\
\text { Level }\end{array}$ & \multicolumn{9}{c}{ Level of investment } & \multicolumn{2}{c}{ Total } \\
\cline { 2 - 6 } & Below 5 lakh & $\mathbf{5}$ to & $\mathbf{2 5}$ lakh & $\mathbf{2 5}$ \& above & & \\
\cline { 2 - 8 } & $\mathbf{f}$ & $\mathbf{\%}$ & $\mathbf{f}$ & $\mathbf{\%}$ & $\mathbf{f}$ & $\mathbf{\%}$ & $\mathbf{f}$ & $\mathbf{\%}$ \\
\hline Less Aware & 1 & 1.54 & 2 & 3.08 & 0 & & 3 & 4.62 \\
Aware & 6 & 9.23 & 2 & 3.08 & 1 & 1.54 & 9 & 13.85 \\
Fairly Aware & 9 & 13.85 & 14 & 21.54 & 4 & 6.15 & 27 & 41.54 \\
Highly Aware & 7 & 10.77 & 10 & 15.38 & 9 & 13.85 & 26 & 40.00 \\
Total & 23 & 35.38 & 28 & 43.08 & 14 & 21.54 & 65 & 100.00 \\
\hline
\end{tabular}

\section{One sample t-test of access to information}

Under the parametric test, one-sample t-test is used to test the hypothesis that there is problem on access in market information for equity investors as alternative hypothesis.

Table 8: One Sample t-test of investors' access to information

\begin{tabular}{lrrr}
\hline Test Value $=\mathbf{0 . 5 0}$ & $\mathbf{t}$ & df & Sig. (2-tailed) \\
\hline Access to market information & 5.609 & 64 & 0.000 \\
\hline
\end{tabular}

The test value is assumed to be 0.50 which is the cutoff point of investors' responses for this study. The critical t-statistics at $5 \%$ level of significance and 64 degree of freedom is 2.000 (2-tailed), which is lesser than calculated t-value. Thus, the null hypothesis is rejected in favor of alternative hypothesis i.e. there is problem on access to market information for equity investors in secondary market.

\section{Suggestions from Investors}

The response section was categorized into 4 statements with yes/no options and 1 open question. The analysis is simply conducted in frequency distribution with percentage. Table 9 shows summary responses for each question.

Table 9: Major suggestions

\begin{tabular}{|c|c|c|c|c|}
\hline \multirow{2}{*}{ Statements } & \multicolumn{4}{|c|}{ Responses } \\
\hline & No & $\%$ & Yes & $\%$ \\
\hline $\begin{array}{l}\text { Do you think the current sources of information are } \\
\text { sufficient? }\end{array}$ & 59 & 90.77 & 6 & 9.23 \\
\hline $\begin{array}{l}\text { Do you think advertisement is necessary to create } \\
\text { investor awareness? }\end{array}$ & 8 & 12.31 & 57 & 87.69 \\
\hline $\begin{array}{l}\text { Do you think the existing brokerage firms are } \\
\text { sufficient to meet the current/market needs? }\end{array}$ & 55 & 84.62 & 10 & 15.38 \\
\hline Do you think new stock exchange is necessary? & 16 & 24.62 & 49 & 75.38 \\
\hline
\end{tabular}

About $91 \%$ respondents are not satisfied with the current sources of information, nearly $88 \%$ are in favor of advertisement, almost $85 \%$ believed that existing 
brokerage firms are not sufficient to meet the current demand and about $75 \%$ feel that new stock exchange is necessary.

Despite the suggestions provided in the above statements, respondents were also prescribed the additional suggestions to increase the investors' awareness in Nepalese capital market through the end of concern authorities. Respondents believed that to enhance the existing level of awareness following suggestions need to be executed: Disseminating timely and sufficient information; Conducting the effective training and workshops; Investors need to be alert to get the information own-self; Advertising through media; Developing proper data storage and management system; Introducing basic investment courses from school level; Government initiatives and support to expand the market; Creating attraction to Non-resident Nepalese in capital market; Introducing online trading system.

\section{CONCLUSION}

In this study, investor awareness and its relationship with investment decision in equity and investors' access to market information were examined. Investor awareness is crucial for the investment decision making and sustainable growth of capital market. The result of the study depicted that equity investors are aware and their level of awareness is high compared to desired level. The finding of the study is that fully aware equity investors have more chances of holding high volume of equity investment. In other words, there is positive correlation between awareness and level of investment. Investors are keen to get market information timely and sufficiently to make a profitable investment. Nepalese capital market is characterized with limited sources of information. The rational fact is that investors need to have good access to market information but the study shows that there is problem on access to information for equity investors in secondary market.

The investor awareness level is found to be affected by the related work experience, understanding of investment environment, learning expectation, and access to market information. Equity investors in secondary market are not satisfied with the available sources of information and efforts of information disseminating mechanism.

Majority of the equity investors provides the suggestions; disseminating timely and sufficient information, conducting the effective training and workshops, investors need to be alert to get the information own-self, advertising through media, developing proper data storage and management system, introducing basic investment courses from school level, government initiatives and support to expand the market, creating attraction to Non-Resident Nepalese in capital market, and introducing online trading system to improve the equity investor awareness in Nepalese capital market.

Equity investors with higher investment have more knowledge/aware in investment than those with lower investment. Equity investors with higher educational background have more investment than those with lower level of education. Mass equity investors in secondary market experienced that existing sources of information are not sufficient and realized the need of advertisement. Similarly, 
majority of them believed that existing brokerage firms are not sufficient to meet the market needs and think the need of new stock exchange.

Since, the objectives of this study are to find out the extent of relationship between investor awareness and volume of equity investment in secondary market and to identify the level of equity investors' access to market information. The results show that there is positive relationship between awareness and equity investment and problem on access to market information. The result of study is consistent with the study of Al-Tamimi and Kali (2009) and Van Rooij et al. (2007).

The findings suggest that level of investment would increase, if various efforts were done to enhance the level of investor awareness. The stakeholders in the securities market has been engaging for investor awareness activities but the investor base or attraction of investors has not been reached in required level. Investors are always intense to get first hand market information and want to be updated to protect their investment. One the other hand, regulating bodies are also trying to protect the investors from the malpractices and fraud in the capital market. With the same line, the research finding shows that there is problem for equity investors to get the information which help to create and expand level of awareness and there is progressive relationship between awareness and level of investment. Thus, researchers would like to suggest regulators with some techniques which help to create investor awareness: Publications for investors; Facilities of hotlines and Toll Free numbers; Websites with up-to-date information; Investors alerts System; Financial Awareness Curriculum; Public/community meetings; Specific investing tools; and Plain language disclosure documents.

In this way, securities regulators can implement the above techniques individually or, two or more simultaneously. But, the regulators must distinguish investor advice from investor awareness and have to think that one approach may not be applicable for the different investor groups. Thus the differentiation of the of investor awareness techniques is essential in practice.

Further research can be conducted by extending the scope of the study to cover the variables including income level and period of residency in capital and major cities.

\section{REFERENCES}

Al-Tamimi, H. A. A. and A. A. B. Kali. 2009. Financial literacy and investment decisions of UAE investors. The Journal of Risk Finance, Vol. 10 (5), Pp. 500-516.

Al-Tamimi, H. 2006. Factors influencing individual investor behavior: an empirical study of the UAE financial markets. The Business Review, Vol. 5 (2), Pp 225-32.

Ameriks, J., and S. P. Zeldes. 2004. How do Portfolio Shares Vary with Wealth? Columbia University, Mimeo.

Baidhya, D. and P. R. Parajuli. 2004. Public offerings of securities. SEBON Journal, Vol. I, Pp. 88-92. 
Bernheim, D. and D. M. Garrett. 2003. The Effects of Financial Education in the Workplace: Evidence from a Survey of Households. Journal of Public Economics, Vol. 87, 1487-1519.

Bogan, V. 2006. Stock Market Participation and the Internet. Journal of Financial and Quantitative Analysis, forthcoming.

Christelis, D., T. Jappelli and M. Padula. 2007. Cognitive Abilities and Portfolio Choice. CSEF Working Paper.

Fodor, B. 2008. Measuring market integrity: a proposed Canadian approach. Journal of Financial Crime, Vol. 15 (3), Pp. 261-268.

Graham, J. R., C. R. Harvey and H. Huang. 2005. Investor Competence, Trading Frequency, and Home Bias. NBER Working Paper \# 11426.

Kafle, D. R. 2007. Building a Dynamic Capital Market. SEBON Journal, Vol. III, Pp. 2-9.

Lusardi, A., and O. S. Mitchell. 2006. Financial Literacy and Planning: Implications for Retirement Well-Being. Pension Research Council WP 2006-1, The University of Pennsylvania, Wharton School, USA.

Mirshekary, S. and S. Saudagaran. 2005. Perceptions and characteristics of financial information users in developing countries: evidence from Iran. Journal of International Accounting, Auditing and Taxation, Vol. 14, Pp 33-54.

Nunnally, J. C. 1978. Psychometric Theory. McGraw-Hill, New York, USA.

Paudyal, S. 2010. Nepalese stock market: development impediments and challenges. SEBON Journal, Vol. IV, Pp. 95-103.

Policy Research Institute. 2008. Monthly Financial Review. Ministry of Finance, Japan, No. 416, Pp. 1.

Van-Rooij, M., R. Alessie and A. Lusardi. 2007. Financial Literacy and Stock Market Participation, Mimeo.

Volpe, R., J. Kotel and H. Chen. 2002. A survey of investment literacy among online investors. Financial Counseling and Planning, Vol. 13 (1), Pp 1-13. 